\title{
The Role of Innovation and Opportunity in Bilateral OECD Trade Performance ${ }^{1}$
}

\author{
Prabuddha Sanyal ${ }^{2}$ \\ American University \\ Dipankar Chhabra \\ American University
}

\begin{abstract}
This paper investigates the specialization pattern of countries in terms of technology and exports and examines the role of innovation intensity and technological opportunity in determining bilateral trade at the aggregate and sectoral level. Some of the major findings are as follows: At the aggregate level, innovation intensity and technological opportunity has positive and significant impact on bilateral trade performance especially during the 1990s. At the sectoral level, innovation intensity affects bilateral trade performance positively mainly in the high-technology sectors. There is also a positive and significant relationship between technological opportunity and bilateral trade for five out of the eighteen sectors, which are the high-technology sectors. An indirect policy implication is that creation of a national innovation system is extremely desirable for economies that are trying to specialize in the high-technology sectors.

\footnotetext{
${ }^{1}$ The authors are extremely grateful to Alan Isaac and Kevin Carey for helpful comments. The remaining errors are solely ours. email: prabuddha_sanyal @hotmail.com.
}

${ }^{2}$ Please address all correspondence to Prabuddha Sanyal. postal address: 123 Scott St, Baltimore, MD 21201,
\end{abstract}


Keywords:Bilateral trade, Innovation Intensity, Technological Opportunity JEL classification: F14, C31, O33. 


\section{Introduction}

Technology plays an important role in economic performance of nations. Various researchers ${ }^{3}$ have pointed out that European countries and the U.S. are "falling behind" technologically relative to Japan. There is also a growing literature that tries to investigate the determinants of trade performance, either for one country, or for a group of countries, in order to assess the factors which influence trade performance of nations. Fagerberg (1987) has shown the positive effect of technology on economic growth and international competitiveness at the aggregate economy level, using a combination of R\&D data and patent statistics. At the sectoral level, Soete (1981), Dosi et al. (1990), and Verspagen (1992) found that technological activity (mainly measured by patents granted in the U.S.) had a positive impact on trade performance. This paper aims to further investigate the relationship between bilateral technology flows and bilateral trade performance for the G-5 countries (U.S., U.K., France, Germany, and Japan), with particular emphasis on the importance of differences in innovation in influencing bilateral trade.

There are two issues concerning the relationship between innovation and trade performance which are addressed in this paper. The first concerns how the determinants of trade vary over countries and industries. This will show whether sector characteristics, such as the level of technological opportunity in the sector, or characteristics common to the country, such as national institutions, are important in influencing trade performance. Dummy variables are included both for the sector and the country of origin to control for the influence of factors that vary across sectors for a particular country, and across countries for a particular sector. Secondly, the paper aims to explore the degree to which countries get access to high levels of technological opportunity, and how this affects trade performance. For this purpose, a dummy variable is constructed to reflect how countries get

\footnotetext{
${ }^{3}$ Tyson (1992) and Freeman et al (1991).
} 
access to high technology or move away from low-tech sectors.

This paper is organized as follows: Section 2 presents an overview of the literature relating the role of technology on trade performance of nations. Section 3 presents the empirical model used in this paper to analyze the determinants of bilateral trade. Section 4 discusses the results both for the whole sample period and the sub-sample periods under investigation. Section 5 makes some concluding remarks and policy implications.

\section{Overview of the Literature}

Empirical studies of trade performance that include innovation as an explanatory variable stem from two different theoretical traditions. The first is the Hecksher- Ohlin model of trade, in which relative factor abundance determines the pattern of trade. The second approach considers differences in technology as an important motive in explaining trade performance. In the first approach, early studies used labor productivity data to explain countries' specialization. ${ }^{4}$ Other studies found R\&D intensity, in addition to the other factors, to be positively related to export performance. Stern and Maskus (1981) examines US trade from 1960 to 1970 using a neo-endowment model. They include human capital and technology (measured by R\&D expenditures) as factors of production, and find considerable evidence for the importance of technology in affecting trade performance. Gustavsson et al. (1996) evaluates the role of technology together with resource endowments and economies of scale on international competitiveness for thirteen OECD countries for the period 1989 to 1991 . They find that both factor endowments and technology has a significant effect on international competitiveness. Additionally, they find scale effects on the industry as well as at the national level, which are caused by local externalities.

\footnotetext{
${ }^{4}$ See for example, Macdougall (1951).
} 
In the second approach, the relationship between technology and international competitiveness dates back to the neo-technological trade theories of the 1960s. ${ }^{5}$ This approach considers differences in technology as the primary motive for differences among nations in terms of trade performance. The 'technology gap' approach emphasizes inter-country differences in innovativeness, as the basis for international trade flows. According to Posner (1961), it is technological change in one country, and not in others that induces exports. Since knowledge is a public good, it will flow to other developing economies. This flow is subject to imitation lags, which is dependent on the capacity of foreign producers to adapt their production structure in order to produce new goods with cheaper labor. The 'product cycle' model can be attributed to Vernon (1966). The conclusions of this model are very similar to the technology gap model. Innovation in leader countries generates new products which pass through different stages of maturity. Initially the new product is produced only in the innovator country. Once the good reaches a particular phase, the production gets localized in other developing economies, where labor costs are lower. This leads to more diffusion of knowledge.

Most of the empirical studies on the technological factors affecting trade performance find strong evidence that domestic innovation to be an important variable. ${ }^{6}$ Most of these studies concentrate on the effects of innovation on a sectoral basis as opposed to the country-wide empirical approach to test endowment theories. Fagerberg (1988) considers 15 OECD countries for the period 1960 to 1983 . The technological proxies used were R\&D expenditures and external patents. The analysis was conducted at the aggregate level rather than on a sectoral basis. He finds that technological competitiveness and 'the ability to deliver on time' were the most important determinants on international competitiveness and growth. Dosi et al. (1990) examined the influence of tech-

\footnotetext{
${ }^{5}$ The technology gap approach and the product cycle approach are the earliest in the literature.

${ }^{6}$ Regardless of input or output measures of innovation.
} 
nology gaps on OECD trade, using a patent based technology measure. They also used different dependent variables for trade performance and found similar results as Fagerberg. Cotsomitis et al. (1991) found little evidence of the role of technology in affecting trade flows. This study was only limited to particular sectors. Amable and Verspagen and Wakelin (1997) found that change in bilateral export market shares among OECD countries was positively dependent on relative R\&D as well as the number of patents. Wakelin (1998) examined the determinants of bilateral OECD trade, with particular emphasis on innovation. Two innovation proxies were used. She finds a positive relationship between relative innovation and bilateral trade performance. The analysis is undertaken at the country level, and for a number of manufacturing sectors. The results confirm that technology gaps partly determine trade, but not in all sectors.

The importance of 'technological opportunity' in determining international trade flows stems from the basic assumption that technology is not a free good. Technological opportunity reflects the ease of innovating given an amount invested in research activities. Nelson and Winter (1982) introduced the idea of 'technological regimes' as determinants of the patterns of innovative activities across industries. Malerbo and Orsenigo (1990) identifies four basic dimensions of opportunity, namely levels, pervasiveness, sources, and variety. A high level of opportunities signifies strong incentives in undertaking innovative activities, and is the probability of innovating for a given amount of resources invested in research. High pervasiveness implies that new knowledge can be applied to several products and markets, and is the basis of the endogenous theory of technological change. Sources refer, to the differences in opportunity among industries. In some industries, opportunity conditions are related to scientific advance made at universities. In other industries, factor intensity determines the advancement of industries (for example, in textiles and wood industries, labor intensity determines how technology will improve). In other sectors (such as 
pharmaceuticals), internal $\mathrm{R} \& \mathrm{D}$ and endogenous learning is the most dominant source of technological innovation. Variety refers to the high level of technological opportunity associated with new technological solutions, approaches, and activities (for example in the office and computing and communications industries). When a dominant form of technology emerges, technological change proceeds along specific trajectories and the variety in technological solutions to a specific problem is reduced. Laursen (1997) examines the extent to which countries get access to sectors with above average growth rate in technological opportunity. He finds that the 'catching up' countries (such as Japan, Finland, Ireland, Austria) have experienced very high levels of growth in terms of technology, measured by the share of U.S. patents. However, they generally appear to have been specialized in the sectors offering low levels of technological opportunity.

For the case of single country models, Greenhalgh (1990) examined the determinants of UK net exports using time series data. Different technology variables were proxied from the SPRU innovation survey. ${ }^{7}$ He finds significant influence of the technology variables on net exports.

Breschi et al.(1996) examine the relationship between trade and technological performance with an emphasis on Switzerland. Measures of revealed comparative advantage and revealed technological advantage were constructed and applied across 49 technological classes. They find that performance of Switzerland at the aggregate level is not satisfactory. This is because Switzerland is not specialized in the high-tech sectors and shows a declining trend in exports of high-tech products. Although there is a positive relationship between trade and technological performance, the relationship is not very strong.

\footnotetext{
${ }^{7}$ The Science Policy Research Unit at the University of Sussex provides an alternative measure of innovation. Significant innovations are defined as 'the successful commercial introduction of new or improved products, processes or materials'. The survey is for the U.K. and covers over 4000 innovations for the period 1945 to 1983.
} 


\section{Empirical Framework and Methodology}

\subsection{Data Set, Definition and Measurement}

The purpose of this paper is to explore how relative innovation, factor endowments (arable land per worker, and relative capital labor ratios), and technological opportunity affect export performance in a cross-section of 10 intra-OECD bilateral trade flows. Five G-5 countries are considered in the sample and 18 industries are included. ${ }^{8}$ The period considered is 1980 to 1998. The data is extracted from STAN, ANBERD and Bilateral trade databases of the OECD. International competitiveness at the industry level may be defined as the ability to sell products in international markets in competition with other producers. Bilateral exports is used as a measure of competitiveness following the existing literature. ${ }^{9}$ The model is as follows: International competitiveness of a country is explained by technological factors (R\&D intensity and technological opportunity) and factor endowments (arable land per worker and relative capital- labor ratio). The specification is as follows:

$$
\begin{aligned}
& \frac{E_{p q s}}{E_{q p s}}=f\left[\left(\frac{K_{p s}}{K_{q s}}\right),\left(\frac{A_{p s}}{A_{q s}}\right),\left(\frac{I_{p s}}{I_{q s}}\right), \text { Du mm ytech }\right]+u_{t s} \\
& u_{t s}=\rho u_{(t-1) s}+\epsilon_{t s}
\end{aligned}
$$

where $E\left(\epsilon_{t s}\right)=0$

$$
E\left(\epsilon_{t s}^{2}\right)=\sigma_{t s}^{2}
$$

and $\operatorname{Cov}\left(\epsilon_{t s}, \epsilon_{t j}\right)=0$ if $s \neq j$

In equation (1), the dependent variable is the ratio of exports from country $p$ to country $q$ over exports from $q$ to $p$ in sector $s$. The explanatory variables are as follows: $K$ represents

\footnotetext{
${ }^{8}$ Two industries have been deliberately dropped from the sample, petroleum and refineries because of relatively poor data and other manufacturing, since it includes different products across economies. Appendix B provides the list of industries considered in the sample.

${ }^{9}$ see for example, Wakelin (1998).
} 
capital stock to number employed. ${ }^{10} A$ represents arable land per worker interacted with a dummy variable for the food industry. ${ }^{11} I$ represents the innovation variable, and is proxied by $\mathrm{R} \& \mathrm{D}$ expenditures undertaken by business enterprises relative to production. This variable gives the relative $\mathrm{R} \& \mathrm{D}$ intensity between two countries $p$ and $q$ in sector $s$. Dummytech represents a variable for technological opportunity following the technological gap theory. ${ }^{12}$ The rationale for including the technological opportunity variable stems from the fact that technological opportunities differ among industries. In some industries opportunity conditions are closely related to scientific advance made at universities. In other sectors, internal R\&D and endogenous learning are the most dominant sources of innovation, yet in other sectors users or suppliers are the most important ones. This variable will signify whether countries are moving into sectors with fast growing technological activity or moving out of sectors with generally stagnating technological activity (such as some of the low-tech sectors including wood products and textiles). The $\mathrm{AR}(1)$ term is included in equation (1) to incorporate serial correlation in the residuals. The parameter $\rho$ denotes the first order serial correlation coefficient. This coefficient lies between -1 and +1 , depending upon whether there is negative or positive serial correlation. If $\rho$ is roughly zero, serial correlation is absent, and the $\mathrm{AR}(1)$ technique is not needed. ${ }^{13}$ The $\epsilon_{t s}$ term in equation (2) is the one period forecast error. The forecast is made by applying the coefficients of the independent variables, and then adding the prediction of the residual from its own past value. The forecast in this process is improved, as

\footnotetext{
${ }^{10}$ The details of construction of the capital stock is given in Appendix A.

${ }^{11}$ Specifically, $A$ represents the product of the dummy variable for each industry with the corresponding arable land per worker.

${ }^{12}$ The technological opportunity variable (dummy variable) is assigned values of $4,3,2$, and 1 respectively, whenever the ratio of the innovation variable $(I)$ was greater (less) than unity for the high-tech and low-tech sectors respectively.

${ }^{13}$ Most of the available tests for autocorrelation shows that if the disturbances are autocorrelated, this will be reflected in the autocorrelations of the least squares residuals. The widely used test is the Durbin- Watson test, and the test statistic is given by:$$
d=\frac{\sum\left(u_{t}-u_{t-1}\right)^{2}}{\sum u_{t}^{2}} \text {. }
$$

If the sample is reasonably large, the test statistic is approximated by $d \cong 2(1-\rho)$
} 
the residuals tends to be smaller. The relationship $f$ is assumed to be linear. The relationship was initially pooled across all the time periods and industries. Therefore, the total number of observations is $10 \times 19 \times 18=3420$, since there are 10 bilateral relationships, 19 years and 18 industries in the sample. This is done to smooth the data for any variation that can occur due to business cycles.

The innovation variable $(I)$ is expected to come up with a positive sign. High R\&D intensity introduces new products in the market and raises the quality of existing goods, which improves trade performance. Process innovations reduce costs and improves competitiveness. Although innovation is an important factor in trade performance, the role of capital deepening in influencing trade performance should not be neglected. If the level of technology for a given vintage of capital does not change over time, and if machines of later vintages are more efficient than older ones, then the average level of technology at point in time will depend on the most recent vintage. Assuming that such embodied technological change is potentially available globally to all producers, this can raise competitiveness of the economy. A positive relationship is also expected between capitallabor ratio and trade performance. Turning to arable land per worker ( $A$ variable), if countries are rich in natural resources such as land, then Hecksher-Ohlin model predicts that countries will export those goods that are more intensive in its factors of production. However, since most of the industries (with the possible exception of food, beverages, shipbuilding, and wood products) require less arable land per worker, it is possible that arable land will play no significant role in international specialization patterns of countries. Hence, the sign of this coefficient is expected to be ambiguous and dependent on the industry under question. Finally, the dummy variable is also expected to come up with an ambiguous sign. If countries tend to specialize in sectors that are fast growing (such as Drugs and Medicines, Office and Computing) in terms of technology, it is expected 
that the coefficient will be positive. On the other hand, if countries move into sectors offering low levels of market opportunity (industries such as metal and mineral products), this variable can have a negative impact on export performance.

\section{The Results}

\subsection{Main Results}

First, the relationship in equation (1) was estimated according to equation (3) with the data pooled for all the industries. $\alpha$ is the intercept term and $u$ is the error term, which follows an $\operatorname{AR}(1)$ process. Following Wakelin (1998) a log-linear model was specified of the following form:

$$
\ln \left(\frac{E_{p q s}}{E_{q p s}}\right)=\alpha+\beta_{1} \ln \left(\frac{K_{p s}}{K_{q s}}\right)+\beta_{2} \ln \left(\frac{A_{p s}}{A_{q s}}\right)+\beta_{3} \ln \left(\frac{I_{p s}}{I_{q s}}\right)+\beta_{4} D u \mathrm{~mm} y \text { tech }+u_{t s}
$$

Estimations were undertaken for three different periods (the full sample period, 1980 to 1989 and 1990 to 1998) and was estimated using OLS. The results for each regressions are given in Column (3) of Tables 1 and 2. The results are consistent with a priori expectations. For the full sample period and the period 1990 to 1998, the coefficient of the arable land per worker is negative and significant. This shows that specialization in natural resources has a negative impact on aggregate trade performance. The capital intensity variable has a positive and significant relationship with aggregate trade performance for all the periods. The innovation variable comes with a positive sign and is significant for the full sample and during the period 1990 to 1998. This result indicates a definite role for innovation in affecting trade performance. Finally, the technological opportunity variable is positive and significant for the full sample and during the period 1990 to 1998 . However, the coefficient is negative and not significant for the period 1980 to 1989 . This shows that G-5 countries in the sample are moving into sectors that promises higher technological opportunity. 
Although the results are consistent with expectations, the pooled specification is restrictive, since it imposes common coefficients across sectors and countries. All the countries in the sample are industrialized but differs in terms of innovation intensity and factor endowments. For example, U.S. has higher research intensity, and has more arable land per worker than other countries in the sample because of its size. In addition, each possesses its unique national system of innovation with different linkages among sectors, and macroeconomic fundamentals, leading to variations at the country level. To take into account the above deficiencies, a sectoral level analysis is also conducted.

\subsection{Sectoral Level Results}

The above data set can be grouped into two dimensions: sectors and bilateral trade flows. There are 10 bilateral flows according to the country of origin and eighteen industries in the sample. A model including sector specific dummies in which the intercept varies across sectors is appropriate to understand how the various explanatory variables affect trade performance across sectors. The dummy variable for technological opportunity reflects national characteristics of innovation, such as economic structure, institutions and government policies, which vary across all sectors for individual countries. Tables 3 to 5 report results for individual industries with a single intercept but with coefficients that vary across sectors. Three different time periods ${ }^{14}$ are considered to understand how innovation intensity, factor intensity and technological opportunity affect trade performance across sectors. Secondly, it is important to examine whether countries are moving into sectors providing greater technological opportunity (especially during the 1990s).

Table 3 reports results for individual industries for the entire sample period. Column 5

\footnotetext{
${ }^{14}$ The time periods considered are the full sample period (1980 to 1998), 1980 to 1989 and 1990 to 1998.
} 
shows that seven of the eighteen industries have positive and significant coefficients on the R\&D intensity variable, indicating that in these sectors innovation have positive influence on trade performance. Three of the industries, namely aerospace, radio, TV and communications, and drugs and medicines are considered high-tech sectors from the OECD (1997) classification of industries. Among other industries for which the innovation intensity variable is significant are medium-high technology sectors such as motor vehicles, electrical and non-electrical machinery sectors. Also, in the rubber and plastic product industry, which is a medium-low tech sector, the coefficient of the innovation variable turns out to be positive and significant. Hence, it is not exclusively high technology industries that invest in research to improve trade performance. The benefits of research can be experienced in manufacturing sectors at different technological levels (possibly through R\&D spillover effects). These results confirm with both Wakelin (1998) and Greenhalgh (1994), in which a number of low technology industries had positive relationship between trade performance and innovation.

In the case of office and computing and metal product industries, we find opposite effects of innovation on trade performance. The office and computing industry is one of the relatively hightech sectors and the results needs to be explained further. First, it is possible that the innovation proxy (relative R\&D intensity) may not be capturing all aspects of innovation. ${ }^{15}$ Secondly, in the OECD classification of industries, products with mixed technology levels are included. In the case of office and computing industry, low technology office machinery is also included in the definition of this sector.

The Dummytech variable, which captures technological opportunity, shows positive and

\footnotetext{
${ }^{15}$ A patent based technological intensity measure can possibly address the above problem, since patents measure innovation output, where as R\&D expenditures measure innovation input. However, patent counts by granting and applicant nations was not available for US and Japan as the granting nation was not available by sectors during the 1980s. Hence, the patent based technological intensity measure could not be undertaken in the present study.
} 
significant coefficients for five out of the eighteen sectors. The sectors where this variable is positive are the high-tech sectors (drugs and medicines, motor vehicles, office and computing, other transport and radio, TV and communications industry). This shows that countries in the sample are moving into sectors with fast growing technological activity during the above time period. This result also confirms that of existing studies such as Laursen (1997), where he finds that a technological opportunity variable is positively related to trade performance for a sample of 20 countries across 17 manufacturing sectors. The technological opportunity variable may include different parts of the national innovation system, such as efficiency of the education system, the financial system, the quality of intra and inter-firm cooperation, and the relationship between the public sector and business firms. ${ }^{16}$

The arable land per worker variable $\left(\frac{A_{p s}}{A_{q s}}\right)$, which measures natural resource endowment of an economy shows positive and significant coefficients for six out of the eighteen sectors and four negative and significant coefficients. In the high-tech sectors, drugs and medicines, radio, TV and communications display a negative relationship between natural resource abundance and trade performance. This may be because the above industries use fewer natural resources in their final products, and thus the export intensity is negatively affected by this variable. The alternative argument may be intra-industry trade in these sectors. Two way trade in similar products in these sectors among the G-5 countries is compatible with the H-O-V model if products are allowed to differ by location of production. Similarly, in the low-tech sectors (food and beverages and textiles) arable land per worker has a negative impact on trade performance. Although these sectors use more land per worker, the products may be very similar across countries (such as red wine in France and U.S.) and hence there is a possibility of intra-industry trade. Bowen et al. (1987), in a study

\footnotetext{
${ }^{16}$ See for example, Lundvall (1992).
} 
of 1967 data on 27 countries and 12 factors, find that about 35 percent violations of one ordering restriction and 50 percent violations of another of the $\mathrm{H}-\mathrm{O}-\mathrm{V}$ predictions and the present results are consistent with that. There were six sectors for which arable land per worker had a positive and significant influence on trade performance. They were motor vehicles, electrical and non-electrical machinery industries in the high-tech sectors. This is because these industries use a substantial amount of natural resources apart from other factors of production in producing the final product. Similarly, in the low-tech sectors, metal products, paper products and rubber and plastic industries are ones where arable land per worker has a positive and significant influence on trade performance.

Turning to the other factor intensity variable (capital stock per worker, $\left(\frac{K_{p s}}{K_{q s}}\right)$, six out of the eighteen industries had positive and significant influence on trade performance. The hightech sectors were usually the ones whose relative capital intensity had a positive influence on trade performance as measured by relative export intensity. This result is consistent with recent empirical evidence. ${ }^{17}$ Investment in new capital stock is a complement to technological change. It increases the capacity and flexibility of production facilities, and adds to the quality of new goods by including embodied technology in capital equipment. The only possible exception was the chemical industry. There are two possible explanations for this. First, it is possible that more labor is employed in this sector relative to capital (for example scientists and researchers); capital intensity is less conducive to export intensity after controlling for other factors that influence trade performance. Secondly, most of the countries in the sample (US, UK, Germany and Japan) are specialized (both in terms of RCA and RTA) in this sector ${ }^{18}$, and there is a substantial possibility of intra-industry trade in this sector. This explains why the estimated coefficient turns out to be negative. Sector specific effects are significant in nine out of the eighteen industries in the sample period. Thus,

\footnotetext{
${ }^{17}$ See for example Gustavsson et al. (1996), Fagerberg (1997), and Wakelin (1998).

${ }^{18}$ See our analysis on Section 4.1 .
} 
international specialization depends on a number of industry characteristics, which are not captured by the explanatory variables. One source of such fixed effects may be the presence of trade surpluses (or deficits) in manufacturing industries in some countries, as well as surpluses (or deficits) of the country group as a whole in some of the industry groups.

In order to understand how innovation intensity, factor intensity and technological opportunity affect trade performance across sectors in two different time periods (during the 1980s and 1990s) and whether countries moved into sectors providing greater technological opportunity (especially during the 1990s), the above analysis is undertaken (equation 1), by dividing the data into two time periods (1980 to 1989 and 1990 to 1998). Equation (1) was then estimated using OLS for these two sub-periods.

Table 4 report results for the period 1980 to 1989. Column (5) shows the impact of relative R\&D intensity on bilateral export intensity. For eight out of the eighteen sectors, relative R\&D intensity has a positive influence on trade performance. The high-tech sectors where this effect was positive were aerospace, chemicals, drugs and medicines, motor vehicles, and radio, TV and communications industry. In aerospace, motor vehicles, and radio, TV and communications industry, the elasticity of export intensity with respect to relative R\&D intensity exceeds unity. In other words, a one percentage point increase in $R \& D$ expenditure of one country relative to the other country raises the export performance by more than one percentage point. The other industries where relative $R \& D$ intensity had a positive influence on export performance are non-metallic mineral products, rubber and plastic products, and textiles industry. This may be because the benefits of research in one sector can be experienced in manufacturing sectors at different technological levels (probably through R\&D spillover effects). The only exception to the above result is the negative impact of R\&D intensity on relative export intensity in the office and computing industry. The 
explanation is the same as in Table 11.

The Dummytech variable, which captures technological opportunity is positive and significant for two out of the eighteen sectors and negative and significant for two of the industries. The sectors where a positive coefficient was found are motor vehicles and other transport and equipment. These industries belong to the medium-high technology sectors and signifies countries moving into the high-tech industries. Similarly, the sectors that have a negative and significant coefficient for this variable are textiles and wood products industries. This signifies that countries are moving out of the low-tech sectors in order to gain relative technological and comparative advantages.

The arable land per worker variable $\left(\frac{A_{p s}}{A_{q s}}\right)$, which measures natural resource endowment of an economy shows positive and significant coefficients for five out of the eighteen sectors and four negative and significant coefficients. This result again points to the ambiguous impact of natural resource endowments on export performance of an economy as explained before. The industries where there was a positive and significant coefficient of this variable are usually the lowtech industries such as metal products, non-metallic minerals, and paper products. The reason is that these industries use substantial amount of land in their final products.

Turning to the other factor intensity variable (capital stock per worker $\frac{K_{p s}}{K_{q s}}$ ), five out of the eighteen industries had positive and significant influence on trade performance. Two industries had negative and significant influence. The industries which had positive and significant influence on export intensity are electrical and non-electrical machinery industries and radio, TV and communications industry, metal products, and rubber and plastic products. The industries which had negative and significant influence are chemicals and food and beverages industries. In the food and beverages industry, relative factor endowments affect trade performance (as measured by relative export intensity) negatively. This result is contrary to expectations. The sector specific effects 
are significant in seven out of the eighteen industries in the period 1980 to 1989 . This may be because there are sector specific effects (such as trade surpluses or deficits in a particular industry or country) which are not explained by the explanatory variables.

Table 5 reports results for the period 1990 to 1998 for individual industries. Column (5) shows the impact of relative R\&D intensity on bilateral export intensity. For seven out of the eighteen sectors, relative $R \& D$ intensity has a positive influence on relative export intensity. The sectors where this influence was positive are again the high-tech industries. Notably, in the drugs and medicines industry, the elasticity of export intensity with respect to R\&D intensity was 3.33 , and this elasticity increased substantially from the period 1980 to 1989. This may be because the G-5 economies specialize in high-tech industries and get more out of their investments in R\&D. The low-tech sectors where this influence is positive are non-ferrous metals and rubber and plastic industry. The industries which have a negative influence of relative $\mathrm{R} \& \mathrm{D}$ intensity on export intensity are office and computing and paper products.

The technological opportunity variable (as measured by Dummytech) has positive and significant influence on trade performance for five out of the eighteen industries and negative and significant influence on five of the eighteen industries. The high-tech industries generally showed a positive and significant coefficient, with the possible exception of the non-electrical machinery sector. This implies that there is not much technological opportunity to be gained in this sector in order to obtain higher export market share. The low-tech industries (namely food and beverages, non-metallic minerals, paper products, and rubber and plastic industry) showed a negative and significant influence of the dummytech variable on relative export intensity. This implies that during this time period (1990 to 1998), most of the G-5 countries moved into sectors providing greater technological opportunity compared to the 1980s. 
The arable land per worker variable $\left(\frac{A_{p s}}{A_{q s}}\right)$, shows positive and significant coefficients for five out of the eighteen sectors and four negative and significant coefficients. This result again points to the ambiguous impact of natural resource endowments on export performance of an economy, as already explained.

The influence of the capital intensity variable $\left(\frac{K_{p s}}{K_{q s}}\right)$ on export intensity has some significant differences compared to the period 1980 to 1989 . we find that seven of the eighteen industries displayed a positive and significant influence on trade performance and three of them displayed negative and significant effect on relative export intensity. The high-tech sectors displayed a positive and significant relationship between relative capital intensity and export intensity. In contrast, lowtech sectors displayed a negative and significant relationship between the above two variables, with the possible exception of rubber and plastic industry. This result again shows that capital intensity augments technological change (embodied technological change) by being a complementary factor to R\&D expenditures. This is because it increases the capacity and flexibility of production facilities, adding to the quality of new goods by including embodied technology in capital equipment. Findings also suggest that seven of the eighteen sectors had significant sector specific effects (both positive and negative).

In interpreting the above results, certain caveats are to be borne in mind. First, in the empirical specification, R\&D activity is assumed to be exogenously given. Thus, a basic issue in endogenous growth theory is not taken into account namely that endogenous innovation occurs in response to profit opportunities. ${ }^{19}$ A related econometric issue involves the simultaneity bias (for example, if relative export intensity also affects $R \& D$ expenditures). Unfortunately, instruments for R\&D expenditures are sadly lacking. However, since relative export intensity in this specifica-

\footnotetext{
${ }^{19}$ See for example, Romer (1986) and Grossman and Helpman (1991).
} 
tion depends on cumulative R\&D expenditures for a 19 year period, simultaneity is not a serious problem. Second, factor endowments are also assumed to be given in the model. In a more realistic specification, endowments such as physical capital are the results of investment decisions determined by expected rates of return. Although, the capital stocks are converted using the perpetual inventory method from the gross domestic capital formation ${ }^{20}$, caution is required in interpreting the results. Finally, the combined direct and indirect impact of R\&D on a country's specialization pattern cannot be estimated as in other authors. ${ }^{21}$ The findings of the present paper compares to the existing literature. Relative R\&D intensity in these high-income (G-5) countries has a positive and significant influence on relative export intensity in the high-tech sectors, except in the office and computing industry. The problem lies in the definition of the office and computing sector. Also, relative R\&D intensity has positive influence in low-tech sectors, such as rubber and plastic industry. Since small open economies are not considered in this sample, no conclusion can be made whether indirect R\&D (as acquired through imports) is important in influencing bilateral trade performance. In the future it may be possible to undertake such a comprehensive study.

\section{Concluding remarks and Policy Implications}

The objective of this paper was to find the specialization pattern (both in terms of technology and exports) of countries in sectors, and to examine the role of differences in innovation and technological opportunity in affecting bilateral trade performance.

At the aggregate level, results show the importance of innovation in influencing bilateral

\footnotetext{
${ }^{20}$ The details of the construction of capital stock are given in Appendix A.

${ }^{21}$ Coe and Helpman (1995) argue that for a sample of high-income countries, competitive advantages and productivity should go hand in hand. They find that returns to R\&D investments are high in the high income countries and for larger countries, domestic R\&D investment matters most, while for small countries R\&D acquired indirectly through imports is the most important source of technological change.
} 
trade. The technological opportunity variable also has a significant impact on bilateral trade performance (especially during the 1990s), showing that countries in the sample are moving into sectors which promise higher opportunity. Regarding factor endowments, the capital intensity variable has a positive and significant impact on aggregate trade performance for all the periods.

At the sectoral level, innovation intensity (as measured by relative R\&D intensity) affects bilateral trade performance positively in seven out of the eighteen industries over the entire sample period. The industries which displayed a positive and significant relationship were mainly the hightechnology sectors, with the exception of the office and computing industry. This result occurs due to the definition of the OECD classification of the office and computing industry, since products with mixed technology levels are included. The technological opportunity variable also comes with the expected sign for the full sample period and is significant for five out of the eighteen industries, which are the high-technology sectors. The results also indicate that during the 1990s, most of the G-5 countries moved into sectors which provided greater technological opportunity, compared to the 1980s. The impact of arable land per worker on bilateral trade performance at the sectoral level is ambiguous at best. Turning to relative capital intensity's impact on bilateral trade performance at the sectoral level, findings reveal that sectors belonging to the high-technology area has a positive impact, with the exception of chemical industry. The possible explanation behind this result lies in countries trading in similar products in this industry. Hence, intra-industry trade may dictate why capital intensity has a negative impact on bilateral trade performance. During the 1990s, there exists a positive and significant relationship between capital intensity and relative export performance for the high-technology sectors and a negative and significant relationship between the above two variables in the low-tech sectors, with the exception of rubber and plastic industry. There is also evidence of sector specific effects that are significant in nine out of the eighteen industries in 
the entire sample period. This source of fixed effect may be due to the presence of trade surpluses (or deficits) in manufacturing industries in some countries, as well as surpluses (or deficits) of the country group as a whole in some of the industry groups.

Overall, there is strong evidence of innovation intensity and technological opportunities significantly influencing bilateral trade performance. This suggests that countries need to specialize in the high-technology sectors in order to gain higher export market shares. An indirect policy implication is that developing countries such as India, Mexico, Brazil, and South Korea which are trying to gain technological opportunities in the high-technology sectors, creation of a national innovation system is extremely desirable. This is important for developing economies to catch up in per capita incomes with the advanced developed economies. 


\section{References}

Amable, B. and B. Verspagen. (1995). The role of technology in market share dynamics. Applied Economics 27: 197-204.

Breschi, S. and R. Helg. (1996). Technological Change and International Competitiveness: The Case of Switzerland. Working Paper 31. Cattaneo University.

Bowen, H.P., E.E. Leamer, and L. Sveikauskus. (1987). Multicountry Multifactor Tests of Factor Abundance Theory. American Economic Review 77: 791-809.

Coe, D.T. and E.Helpman. (1995). International R\&D Spillovers. European Economic Review 39: 859-887.

Cotsomitis, J. et al. (1991). A Re-examination of the Technology Gap Theory of Trade: Some Evidence from Time Series Data for OECD Countries. Weltwirtshaftliches Archiv 127: 792-799. Deardorff, A.V. (1984). Amsterdam. In R.W.Jones, and P.B.Kenen (eds.), Handbook of International Economics, Vol. 1. Testing trade theories and predicting trade flows. North Holland: $467-517$.

Dosi, G., K. Pavitt, and L. Soete. (1990). The Economics of Technological Change and International Trade. Harvester Wheatsheaf Publishers: Brighton.

Fagerberg, J. (1988). International Competitiveness. The Economic Journal 98: 355-374.

Fagerberg, J. (1997). Brookfield,VT. In J. Fagerberg et al. (eds.), Technology and International Trade. Competitiveness, Scale and R\&D. Edward Elgar: 38-55.

Fagerberg, J. and B. Verspagen. (2000). Dordrecht. In B. Van Ark, S.K. Kuipers and G. Kuper (eds.), Productivity, Technology and Economic Growth. Productivity, R\&D Spillovers and Trade. Kluwer Academic Publishers: 345-360.

Freeman, C., M. Sharp, and W. Walker. (1991). Technology and the Future of Europe. Pinter 
Publishers: London.

Fransman, M. (1999). Visions of Innovation: The Firm and Japan, Oxford University Press: New York.

Gordon, R.J. (2002). Princeton, NJ. In B.Steil et al. (eds.), Technological Innovation and Economic Performance. The United States. Princeton University Press: 49-73.

Greenhalgh. C. (1990). Innovation and Trade Performance in the UK. The Economic Journal 100: $105-118$.

Grossman, G.M. and E. Helpman. (1991). Innovation and Growth in the Global Economy. MIT Press: Cambridge.

Gustavsson, P., P. Hansson, and L. Lundberg. (1999). Technology, Resource Endowments and International Competitiveness. European Economic Review 43(8): 1501-1530.

Hatzichronoglou, T. (1997). Revision of the High Technology Sector and Product Classification. STI Working Paper 2..OECD, Paris.

Jorgenson, D.W., and R. Landau. (1993b). Tax Reform and the Cost of Capital: An International Comparison. Brookings Institution: Washington, DC.

Langlois, R.N. (2002). Princeton, NJ. In B.Steil et al. (eds.), Technological Innovation and Economic Performance. Computers and Semiconductors. Princeton University Press: 265-284.

Laursen, K. (1997). The Impact of Technological Opportunity on the Dynamics of Trade Performance. Working Paper 96-12. DRUID.

Leamer, E.E. (1994). Oxford. In Greenaway, D. and L.A. Winters (eds.), Surveys in International Trade. Testing Trade Theories. Blackwell Publishers.

Lundvall, B.A. (1992). National Systems of Innovation: Towards a Theory of Innovation and Interactive Learning. Pinter Publishers: London. 
MacDougall, G.D.A. (1951). British and American Exports: A Study Suggested by the Theory of Comparative Costs. Economic Journal. 61: 697-724.

Malerba, F. and L. Orsenigo. (1990). Cambridge. In A. Heertje et al. (eds.), Evolving Technologies and Market Structure. Technological Regimes and Patterns of Innovation: A Theoretical and Empirical Investigation of the Italian Case. Cambridge University Press.

Nelson, R.R. (1993). National Innovation Systems: A Comparative Analysis. Oxford University Press: New York.

Nelson, R.R. and S. Winter. (1982). An Evolutionary Theory of Economic Change. Harvard University Press: Cambridge, MA.

OECD. (2000a). STAN Database for Industrial Analysis, OECD, Paris.

OECD. (2000b). ANBERD. Basic Science and Technology Statistics, OECD, Paris.

OECD. (2000c). Bilateral Trade Database, OECD, Paris.

Posner, M.V. (1961). International Trade and Technical Change. Oxford Economic Papers, 13: $323-341$.

Romer, P.M. (1986). Increasing Returns and Long-Run Growth. Journal of Political Economy, 94: 1002-1037.

Soete, L. (1981). A General Test of Technological Gap Trade Theory. Weltwirtshaftliches Archiv, 117: $638-660$.

Soete, L. (1987). The Impact of Technological Innovation on International Trade Patterns: The Evidence Reconsidered. Research Policy, 16: 101-130.

Tyson, d'Andrea L. (1992). Who's Bashing Whom? Trade Conflict in High-Technology Industries. Institute for International Economics, Washington, DC.

Vernon, V. (1966). International Investment and International Trade in the Product Cycle. Quar- 
terly Journal of Economics, LXXX: 190-207.

Verspagen, B. and K. Wakelin. (1997). International Competitiveness and its determinants. Journal of International Applied Economics, 11(2): 177-190.

Wakelin, K. (1998). The Role of Innovation in Bilateral OECD Trade Performance. Applied Economics, 30: 1334-1346. 